\title{
PERSENTASE LIMBAH PADA INDUSTRI SAWMILL PT. BERAU KARYA INDAH DI KABUPATEN TELUK BINTUNI
}

\section{(Sawdust Percentage Emanating from PT. Berau Karya Indah Industrial Sawmill in District of Teluk Bintuni)}

\author{
YAYA $^{1}$, RUSDI ANGRIANTO $^{1 凶}$, YOHANES Y. RAHAWARIN $^{1}$ \\ Jurusan Kehutanan, Fakultas Kehutanan Universitas Papua Manokwari, Papua Barat, 98314. \\ Tlp/Fax: +62986211065. \\ ${ }^{\square}$ Penulis Korespondensi: Email: rusdiangrianto@yahoo.com \\ Diterima: 22 Feb 2020| Disetujui: 30 Mar 2020
}

\begin{abstract}
Abstrak. Tujuan penelitian ini adalah untuk mengetahui jenis limbah dan persentase limbah yang dihasilkan industri kayu gergajian (sawmill). Penelitian ini dilaksanakan pada industri sawmill PT. Berau Karya Indah, Kabupaten Teluk Bintuni. Pengolahan data dilakukan secara tabulasi dan ditampilkan dalam bentuk tabel dan gambar. Hasil penelitian menunjukan bahwa persentase limbah yang dihasilkan dari limbah serbuk gergaji sebesar 20,69 \% dan limbah sabetan/potongan sebesar 29,03 $\%$. Berdasarkan persentase limbah pada tiap unit mesin/tahapan diketahui bahwa total limbahnya sebesar 49,73\% yang terdiri dari : mesin breakdown saw, limbah yang dihasilkan berupa serbuk gergaji dengan persentase 4,20\%, mesin ponny, limbah yang dihasilkan berupa serbuk gergaji dengan persentase $11,50 \%$, mesin Resaw, limbah yang dihasilkan berupa serbuk gergaji dan sabetan dengan persentase limbah sebesar $27 \%$, mesin cross cut, limbah yang dihasilkan berupa serbuk gergaji dan sabetan/potongan dengan persentase limbah sebesar 7,02\%. Bentuk pemanfaatan limbah hasil proses pengolahan kayu berupa sabetan atau potongan sebagian dimanfaatkan untuk bahan packing/palet, namun sebagian besar limbah baik sabetan maupun serbuk gergaji belum dimanfaatkan secara maksimal mengingat lokasi industri yang jauh dari lokasi pemukiman warga.

Kata kunci: kayu gergajian, limbah, pengolahn kayu, serbuk gergaji, bentuk pemanfaatan

Abstract. The goal of this study was to understand types of wood waste and its percentage emanating from sawmill industry. The study situated in sawmill industry of PT. Berau Karya Indah, district of Teluk Bintuni. Data were performed in tabulation and exhibited in tables and images. The results indicated that wood waste obtained from wood processing was about $49.73 \%$ that consisted of wood sawdust around 20.69\%, slash waste was about 29.03\%. In detail, presentation of each detailed unit machine was elaborated such as: breakdown saw produced about $4.20 \%$, ponny produced wood sawdust approximately $11.50 \%$, resaw indicated sawdust roughly $27 \%$, while from crosscut, the process produced sawdust approximately $7.02 \%$. Another reuse wood waste was noticed for packing from the slash waste, but the overall wood waste has not been used proportionally due to lack on community's engagement.
\end{abstract}

Keywords: sortiment, wood waste, wood processing, wood sawdust, type of use 


\section{PENDAHULUAN}

Hutan merupakan salah satu sumberdaya alam yang berperan penting bagi kelangsungan hidup manusia dan makhluk lainnya, sehingga harus di jaga kelestariannya. Sumberdaya yang potensinya tinggi dan sudah diakui keberadaannya namun pemanfaatannya yang belum optimal adalah sumberdaya hutan. Sedemikian besarnya peranan sumberdaya hutan sehingga Indonesia menjadi suatu negara yang disebut sebagai paru-paru dunia. Produkproduk yang dihasilkan dari sektor ini pun mempunyai kontribusi yang penting dalam perolehan devisa negara. Faktor sumberdaya hutan yang banyak tersedia dan besarnya permintaan pasar mendorong bermunculannya industri-industri pengolahan kayu, mulai dan industri penggergajian, plywood, pulp dan kertas, furniture serta industri pengolahan lainnya.

Papua dengan luas hutan yang diperuntukkan fungsinya sebagai hutan produksi tetap seluas $\pm 10.585 .210 \mathrm{Ha}$ dan hutan produksi yang dapat dikonversikan seluas 9.262.130 Ha. Namun pembangunan kehutanan di Papua masih terdapat kendala-kendala, dimana nilai ekonomi dan peningkatan taraf hidup belum dapat dirasakan masyarakat di dalam dan sekitar hutan (Marwa et al. 2019). Kebijakan pembangunan kehutanan yang selama ini berorientasi pengelolaan kayu dan komoditi hasil hutan dikhawatirkan akan mengganggu kelestarian fungsi hutan. Oleh sebab itu pembangunan kehutanan dituntut untuk lebih memperhatikan keseimbangan aspek ekonomi, ekologi dan sosial sebagai indikator pengelolaan sumberdaya hutan secara lestari. Sejalan dengan pelaksanaan otonomi khusus Papua, maka diperlukan pertimbangan kondisi sumberdaya hutan sebagai penyangga kehidupan, faktor produksi barang dan jasa, industri primer dan faktor penunjang antara lain sumberdaya manusia, kelembagaan yang memadai (Dinas Kehutanan Provinsi Papua 2002).

ICW (2004b) menjelaskan bahwa setelah diterbitkannya UU Nomor 41 tahun 1999 tentang Kehutanan, maka dikeluarkan Keppres Nomor 96 tahun 2002 yang orientasinya mengatur pasokan bahan baku kayu serta industri pengolahan kayu dalam bidang usaha yang terbuka dan bidang usaha yang tertutup bagi penanaman modal. Pertimbangan utama Keppres ini adalah dalam rangka menghadapi perkembangan ekonomi global dan untuk meningkatkan arus pemodalan di Indonesia serta mewujudkan struktur perekonomian nasional yang kokoh. Kondisi ini berbeda dengan semangat UU Nomor 5 tahun 1967 tentang Kehutanan dengan segala fasilitas dan kemudahan untuk menjadikan sektor kehutanan menjadi sumber devisa negara. Keluarnya PP Nomor 21 tahun 1970 yang mewajibkan setiap pemegang HPH untuk mendirikan industri pengolahan kayu merupakan kebijakan yang berusaha meningkatkan penerimaan sektor kehutanan serta memberikan kemudahan penjaminan suplai bahan baku industri dalam negeri.

Industri primer hasil hutan kayu yang banyak bermunculan adalah industri penggergajian kayu. Industri kayu ini mengolah kayu bulat atau kayu gergajian lain yang dibutuhkan sebagai bahan baku bagi industriindustri hilir antara lain, seperti meubel, bahan bangunan dan lain sebagainya (Rianto dkk. 2019). Kondisi ini didukung dengan kebijakan pemerintah yang bertujuan meningkatkan nilai jual kayu serta mengurangi ekspor kayu bulat dan meningkatkan ekspor kayu gergajian (kayu olahan).

Menurut Keppres Nomor 96 tahun 2002, Papua merupakan wilayah yang terbuka bagi penanaman modal dibidang industri pengolahan kayu baik industri kayu lapis maupun industri penggergajian kayu. Namun fakta menunjukkan bahwa berlimpahnya sumber bahan baku kayu 
mendorong industri pengolahan kayu menjadi boros dan tidak efisien menggunakan bahan baku, bahkan tidak mampu mewujudkan peningkatan penerimaan negara secara signifikan yang bersumber dan industri pengolahan kayu (ICW 2004a). Salah satu bentuk pemborosan dan ketidakefisien penggunaan bahan baku ditunjukkan oleh rendemen produksi yang cenderung menurun, ini berarti limbah industri pengolahan kayu cenderung meningkat dengan tingkat pemanfaatan yang relatif sedikit. Penelitian ini bertujuan untuk mengetahui Jenis limbah dan persentasi limbah yang dihasilkan industri kayu gergajian (sawmill) PT. Berau Karya Indah di Kabupaten Teluk Bintuni.

\section{METODE PENELITIAN}

Penelitian dilaksanakan pada industri kayu gergajian (sawmill) PT. Berau Karya Indah Kampung Tirasai Kabupaten Teluk Bintuni. Waktu penelitian dilaksanakan dari tanggal 28 April 2013 sampai tanggal 28 Mei 2013.

\section{Metode dan Teknik Penelitian}

Metode yang digunakan dalam penelitian ini adalah metode deskriptif dengan teknik observasi lapang yaitu dengan melihat besarnya limbah yang dihasilkan pada industri kayu gergajian (sawmill) PT.Berau Karya Indah di Kabupaten Teluk Bintuni.

\section{Variabel Penelitian}

Variabel yang diamati dalam penelitian meliputi :

1. Volume kayu bulat

2. Volume kayu gergajian

3. Volume limbah

\section{Pelaksanaan Penelitian}

\section{Pengambilan Contoh}

Pengambilan contoh dilakukan secara langsung di lapangan yaitu dengan mengambil kayu bulat, sortimen produk serta limbah yang dihasilkan dari proses produksi industri pengolahan kayu gergajian PT. Berau Karya Indah.

\section{Pengumpulan Data}

Pengumpulan data untuk kayu bulat dan sortimen kayu gergajian (samwill) meliputi ukuran panjang dalam meter $(\mathrm{m})$, lebar dalam centi meter $(\mathrm{cm})$ dan tebal dalam centi meter (cm) yang pengambilannya meliputi beberapa tahap :

1. Volume kayu bulat

Volume kayu bulat dihitung dengan menggunakan rumus :

$$
V=\frac{1 / 4 \pi D^{2} \times P}{10.000}
$$

Dimana:

$\mathrm{V}=$ Volume kayu bulat $(\mathrm{m} 3)$

$\mathrm{D}=$ Diameter $(\mathrm{cm})$

$\mathrm{P}=$ Panjang $(\mathrm{m})$

\section{Volume kayu gergajian}

Volume kayu gergajian dihitung dengan mengunakan rumus :

Dimana:

$$
V=\frac{p \times 1 \times t}{10.000}
$$

$$
\begin{aligned}
& \mathrm{V}=\text { Volume kayu gergajian }(\mathrm{m} 3) \\
& \mathrm{p}=\text { Panjang }(\mathrm{cm}) \\
& \mathrm{l}=\text { Lebar }(\mathrm{cm}) \\
& \mathrm{t}=\text { Tebal }(\mathrm{cm})
\end{aligned}
$$

\section{Pengolahan dan Analisis Data}

\section{Perhitungan volume kayu gergajian}

Volume kayu gergajian dihitung dengan menggunakan rumus Brereton Metrik, sesuai surat keputusan Direktur Jenderal Bina Produksi Kehutanan Nomor: P.02/VI$\mathrm{BPPHH} / 2005$ tentang Peraturan Pengujian Kayu Gergajian Rimba Indonesia dan Standar Nasional Indonesia (SNI) Kayu Gergajian Rimba Nomor 7537-2:2010, sebagai berikut: 


$$
\mathrm{V}=\frac{\mathrm{p} \times \mathrm{l} \times \mathrm{t}}{10.000}
$$

Dimana:

$\mathrm{V}=$ Volume kayu gergajian (m3)

$\mathrm{p}=$ Panjang $(\mathrm{cm})$

$1=$ Lebar $(\mathrm{cm})$

$\mathrm{t}=$ Tebal $(\mathrm{cm})$

\section{Perhitungan limbah}

Penghitungan limbah kayu gergajian dihitung dengan menggunakan rumus sebagai berikut :

Dimana :

$$
\mathbf{V L g}=\mathbf{V b b}-\mathbf{V k g}
$$

VLg : Volume limbah kayu gergajian

$\mathrm{Vbb}$ : volume bahan baku

Vkg : volume kayu kayu gergajian (produk)

Sedangkan persentase limbah dihitung dengan menggunakan rumus sebagai berikut :

$$
L \%=\frac{V_{L g}}{V_{b b}} \times 100 \%
$$

Dimana :

L\% : Persentase limbah

VLg : Volume limbah kayu gergajian

Vbb : Volume bahan baku

\section{Rendemen}

Rendemen produksi kayu gergajian dihitung dengan menggunakan rumus sebagai berikut :

$$
\mathrm{R}=\frac{\mathrm{V}_{\mathrm{kg}}}{\mathrm{V}_{\mathrm{kb}}} \times 100 \%
$$

Dimana:

R : Rendemen produksi kayu gergajian

Vkg : Volume kayu gergajian

Vkb : Volume kayu bulat

Data yang terkumpul disusun secara tabulasi dan dianalisis secara deskriptif.

\section{HASIL DAN PEMBAHASAN}

\section{Bahan Baku Industri}

PT. Berau Karya Indah merupakan Ijin Usaha Industri Primer yang berada dalam kawasan IUPHHK PT. Manokwari Mandiri Lestari. Perusahaan memperoleh pasokan bahan baku dalam bentuk kayu bulat melalui kerjasama dengan PT. Manokwari Mandiri Lestari. Dalam mendukung pasokan bahan baku ke depan perusahaan akan kerjasama dengan perusahaan lain sebagai pemasok bahan baku, yang mana hal tersebut merupakan salah satu cara perusahaan dalam mengimplementasikan keputusan bersama Gubernur Papua dan Gubernur Papua Barat dalam hal peredaran hasil hutan kayu.

Produksi kayu bulat yang digunakan sebagai bahan baku yang telah ditimbun di log pond PT. Manokwari Mandiri Lestari terlebih dahulu diseleksi sesuai kriteria yang ditetapkan PT. Berau Karya Indah. Kayu bulat hasil seleksi selanjutnya diangkut dengan menggunakan angkutan darat milik PT. Manokwari Mandiri Lestari ke tempat penimbunan bahan baku PT. Berau Karya Indah.

Di tempat penimbunan bahan baku PT. Berau Karya Indah, sebelum diolah terlebih dahulu dilakukan pengukuran ulang dan seleksi yang selanjutnya dilakukan pemotongan untuk memperoleh ukuran panjang dengan menggunakan chain saw. Pemotongan ukuran panjang disesuaikan dengan kondisi fisik kayu, permintaan pasar dan ukuran mesin pengolah. Dari hasil penelitian terhadap limbah produksi yang dihasilkan dalam proses penggergajian menggunakan sampel bahan baku (kayu bulat) sebanyak 24 batang, seperti pada tabel 1 .

\section{Jenis Mesin Industri dan Proses Produksi}

Dalam proses produksi pada PT. Berau Karya Indah menunjukan jenis mesin yang berbeda-beda sesuai jenis produksi. Berdasarkan layout yang ada, terlihat bahwa proses produksi menggunakan beberapa tipe mesin seperti : 

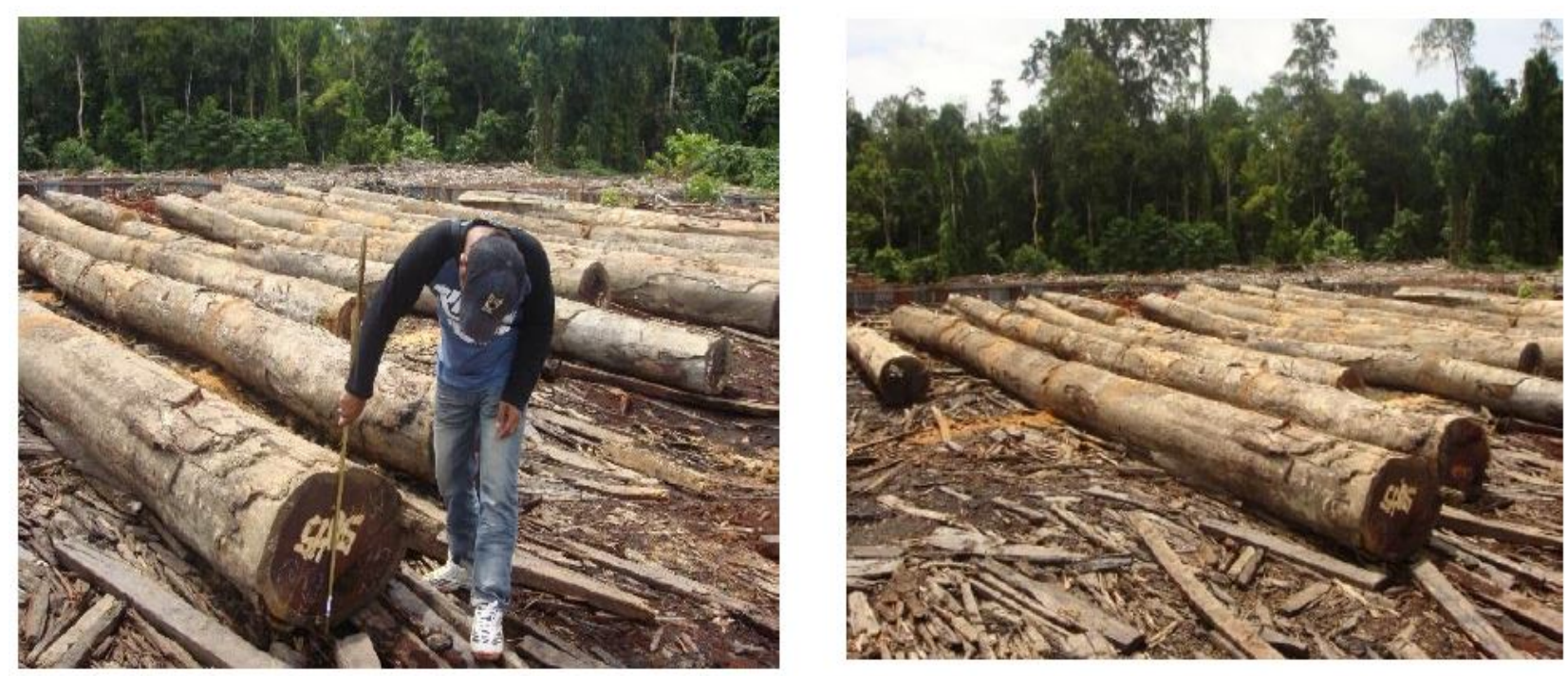

Gambar 1. Pengukuran kayu bulat (bahan baku) dan pemotongan batang

Tabel 1. Hasil pengukuran kayu bulat (bahan baku industri)

\begin{tabular}{lllccc}
\hline No. & No. batang & Jenis kayu & Panjang $(\mathrm{m})$ & Diamater $(\mathrm{Cm})$ & Volume $\left(\mathrm{m}^{3}\right)$ \\
\hline 1. & $4972 / 21 \mathrm{~J}$ & Merbau & 15,00 & 67 & 5,29 \\
2. & $4991 / 21 \mathrm{~K}$ & Merbau & 9,90 & 102 & 8,09 \\
3. & $5187 / 20 \mathrm{~K}$ & Merbau & 13,50 & 57 & 3,44 \\
4. & $4969 / 21 \mathrm{~J}$ & Merbau & 14,40 & 103 & 12,00 \\
5. & $5172 / 21 \mathrm{~K}$ & Merbau & 21,90 & 68 & 7,95 \\
6. & $4975 / 21 \mathrm{~J}$ & Merbau & 19,50 & 60 & 5,51 \\
7. & $5175 / 21 \mathrm{~K}$ & Merbau & 11,40 & 65 & 3,78 \\
8. & $5051 / 21 \mathrm{~K}$ & Merbau & 14,10 & 45 & 2,24 \\
9. & $5182 / 21 \mathrm{~K}$ & Merbau & 8,40 & 76 & 3,81 \\
10. & $4946 / 21 \mathrm{~K}$ & Merbau & 10,60 & 65 & 3,52 \\
11. & $3914 / 21 \mathrm{G}$ & Merbau & 16,10 & 48 & 2,91 \\
12. & $4971 / 21 \mathrm{~J}$ & Merbau & 13,00 & 56 & 3,20 \\
13. & $5068 / 21 \mathrm{~K}$ & Merbau & 8,20 & 60 & 2,32 \\
14. & $5059 / 21 \mathrm{~K}$ & Merbau & 9,50 & 78 & 4,54 \\
15. & $2146 / 22 \mathrm{G}$ & Merbau & 6,80 & 57 & 1,74 \\
16. & $1413 / 22 \mathrm{H}$ & Merbau & 7,70 & 70 & 2,96 \\
17. & $5237 / 20 \mathrm{~K}$ & Merbau & 15,50 & 66 & 5,30 \\
18. & $2003 / 22 \mathrm{H}$ & Merbau & 5,30 & 79 & 2,60 \\
19. & $4977 / 21 \mathrm{~K}$ & Merbau & 5,70 & 96 & 4,13 \\
20. & $2140 / 22 \mathrm{H}$ & Merbau & 5,70 & 96 & 4,13 \\
21. & $5082 / 21 \mathrm{~K}$ & Merbau & 5,60 & 102 & 4,58 \\
22. & $5185 / 21 \mathrm{~K}$ & Merbau & 17,60 & 72 & 7,17 \\
23. & $5 / 20 \mathrm{~K}$ & Merbau & 19,60 & 80 & 9,85 \\
24. & $4993 / 21 \mathrm{~K}$ & Merbau & 18,10 & 56 & 4,46 \\
\hline
\end{tabular}




\section{Mesin utama (breakdown saw)}

Merupakan mesin pembelah, pada proses mesin ini log yang telah ditimbun di pembahanan diangkut dengan menggunakan hoiz ke log deck dan selanjutnya diangkut untuk dipotong-potong sesuai dengan ukuran yang telah ditetapkan sebelumnya. Pada tahapan ini dilakukan pemotongan samping kayu bulat dengan memperhatikan bentuk kayu, retak/cacat dan panjang, limbah yang terjadi pada tahap ini adalah limbah babad berupa serbuk kayu.

\section{Mesin belah (ponny)}

Belahan kayu bulat setelah melalui mesin breakdown saw dibawa dengan menggunakan conveyor untuk selanjutnya dibelah dengan menggunakan mesin ponny. Pada tahapan ini kayu dibelah sesuai ketebalan yang diinginkan konsumen. Limbah yang dihasilkan pada proses ini berupa limbah padat yaitu serbuk kayu.

\section{Mesin belah (resaw)}

Kayu hasil pembelahan pada proses sebelumnya dialihkan dengan menggunakan conveyor ke mesin resaw. Pada tahapan ini kayu dibelah untuk mendapatkan lebar yang diinginkan sesuai dengan permintaan pasar. Limbah yang dihasilkan berupa serbuk kayu dan sabetan.

\section{Mesin potong (cross cut)}

Kayu hasil pembelahan pada proses sebelumnya dialihkan ke mesin cross cut untuk di potong ujung-ujungnya sehingga diperoleh ukuran panjang sesuai permintaan pasar. Pada tahapan ini sortimen diseleksi untuk memisahkan antara sortimen yang baik dan yang cacat, limbah yang dihasilkan berupa serbuk kayu dan sabetan/potongan. Produk kayu olahan hasil dari tahapan cross cut kemudian diseleksi berdasarkan ukurannya, yang selanjutnya disusun berdasarkan ukuran panjang dan kemudian dipasang stick untuk mengatur sirkulasi udara. Setelah proses ini kayu olahan bisa langsung di packing dan diangkut ke gudang penyimpanan /penimbunan. Namun ada juga yang dimasukan ke ruang pengeringan (klin dry), proses ini dilakukan berdasarkan permintaan konsumen.

\section{Limbah Produksi}

Berdasarkan layout industri terdapat limbah yang berbeda-beda sesuai jenis mesin pengolah. limbah pada mesin breakdown saw. Mesin breakdown saw merupakan mesin pembelah, dimana pada proses mesin ini dilakukan pemotongan samping kayu dengan memperhatikan bentuk kayu, retak/cacat dan panjang, biasanya untuk satu kayu bulat dibelah menjadi beberapa bagian besar sesuai ukuran diamater. Limbah yang terjadi pada tahap ini adalah limbah babad berupa serbuk kayu. Pengukuran volume limbah pada mesin ini dilakukan dengan dua cara, yaitu : pertama, pengukuran dengan menggunakan stapel meter, dimana serbuk yang dihasilkan dari mesin ini dikumpulkan dan dimasukan dalam suatu tempat (berbentuk kotak). Maka dari ukuran kotak (panjang $\times$ lebar $\times$ tinggi) tersebut kita dapat menghitung volume limbah tersebut. Kedua dengan menghitung ketebalan mata gergaji (tebal rantai gergaji pada mesin breakdown saw adalah $5 \mathrm{~mm}$ ), dimana tebal mata gergaji di anggap sebagai tebal dan untuk lebar, yaitu lebar sayatan gergaji (diamater kayu) sedangkan untuk panjang yaitu panjang kayu bulat yang selanjutnya untuk mendapat volume limbah dengan cara mengkalikan (panjang $\times$ lebar $\times$ tinggi). Hasil perhitungan volume limbah pada tahapan ini diperoleh limbah sebanyak $4,2 \%$, yaitu dari bahan baku kayu bulat sebanyak $115,52 \mathrm{~m}^{3}$, dihasilkan limbah serbuk kayu sebanyak $4,8518 \mathrm{~m}^{3}$.

\section{Limbah pada mesin ponny}

Mesin ponny merupakan mesin pembelah dimana pada tahapan ini kayu dibelah untuk mendapatkan ketebalan sesuai permintaan 
pasar. Limbah yang dihasilkan pada proses ini berupa limbah serbuk kayu. Sehingga pengukuran volume limbah pada mesin ponny dilakukan sama halnya pada mesin breakdown saw, yaitu dengan menggunakan stapel meter dan ketebalan mata gergaji dimana tebal rantai gergaji pada mesin ponny adalah $3 \mathrm{~mm}$. Hasil perhitungan volume limbah pada tahapan ini diperoleh limbah sebanyak $12 \%$ atau sebanyak $11,5 \%$ dari bahan baku asal (kayu bulat), yaitu dari bahan baku sebanyak 110,6682 $\mathrm{m}^{3}$, dihasilkan limbah serbuk kayu sebanyak $13,2848 \mathrm{~m}^{3}$.

Tabel 2. Persentase limbah pada mesin pengolahan ponny

\begin{tabular}{ccccc}
\hline \multicolumn{3}{c}{ Bahan baku } & \multicolumn{3}{c}{ Limbah (serbuk) } \\
\hline Keping & Volume & Volume & Persentase dari bahan baku & Persentase dari bahan baku \\
$($ Kpg) & $\left(\mathrm{m}^{3}\right)$ & $\left(\mathrm{m}^{3}\right)$ & mesin $(\%)$ & Kayu bulat $(\%)$ \\
118 & 110,6682 & 13,2848 & 12,00 & 11,50 \\
\hline
\end{tabular}

\section{Limbah pada mesin resaw}

Resaw merupakan mesin pembelah dimana pada tahapan ini kayu dibelah untuk mendapatkan lebar sesuai permintaan pasar. Pada tahapan ini sekaligus dilakukan pemisahan antara sisa kulit kayu sehingga limbah yang dihasilkan berupa sabetan dan serbuk kayu. Pengukuran limbah serbuk dilakukan dengan menggunakan stapel meter dan menghitung ketebalan mata gergaji dimana tebal rantai gergaji pada mesin resaw adalah 3 mm. Sedangkan untuk pengukuran volume sabetan karena bentuknya tidak beraturan maka penghitungan dilakukan dengan menggunakan sistem stapel meter.

Hasil perhitungan volume limbah secara keseluruhan (serbuk dan sabetan) pada tahapan ini diperoleh limbah sebanyak 32, $02 \%$ atau sebanyak $27 \%$ dari bahan baku asal (kayu bulat), yaitu dari bahan baku sebanyak 97,3834 $\mathrm{m}^{3}$, dihasilkan limbah keseluruhan sebanyak $31,1904 \mathrm{~m}^{3}$.

Tabel 3. Persentase limbah pada mesin pengolahan resaw

$\begin{array}{ll}\text { Bahan baku } & \text { Limbah } \\ \text { (produk pony) } & \end{array}$

\begin{tabular}{cccccccc}
\cline { 2 - 7 } & & \multicolumn{3}{c}{ Serbuk } & \multicolumn{3}{c}{ Sabetan } \\
\hline Keping & Volume & Volume & i & b & Volume & i & b \\
$($ Kpg $)$ & $\left(\mathrm{m}^{3}\right)$ & $\left(\mathrm{m}^{3}\right)$ & $(\%)$ & $(\%)$ & $\left(\mathrm{m}^{3}\right)$ & $(\%)$ & $(\%)$ \\
1.824 & 97,3834 & 4,6208 & 4,74 & 4,00 & 26,5696 & 27,28 & 23,00 \\
\hline
\end{tabular}

Keterangan :

$\mathrm{i} \%$ : Persentase dari bahan baku mesin

$\mathrm{b} \%$ : Persentase dari bahan baku kayu bulat

\section{Cross cut}

Pada tahapan mesin ini kayu di potong ujung-ujungnya sehingga diperoleh ukuran panjang sesuai permintaan pasar, sehingga limbah yang dihasilkan berupa serbuk kayu dan potongan. Pengukuran limbah serbuk gergaji dilakukan dengan menggunakan stapel meter dan ketebalan mata gergaji dimana tebal rantai gergaji pada mesin cross cut adalah $3 \mathrm{~mm}$. Sedangkan untuk pengukuran volume potongan/sabetan karena bentuknya tidak beraturan maka penghitungan dilakukan dengan 
menggunakan sistem stapel meter. Dari hasil perhitungan volume limbah secara keseluruhan (serbuk dan potongan) pada tahapan ini diperoleh limbah sebanyak $12,26 \%$ atau sebanyak 7,02\% dari bahan baku asal (kayu bulat), yaitu dari bahan baku sebanyak 66,1930 $\mathrm{m}^{3}$, dihasilkan limbah keseluruhan sebanyak $8,1187 \mathrm{~m}^{3}$.

Tabel 4. Persentase limbah pada mesin pengolahan cross cut

\begin{tabular}{|c|c|c|c|c|c|c|c|}
\hline \multirow{2}{*}{\multicolumn{2}{|c|}{$\begin{array}{c}\text { Bahan baku } \\
\text { (produk cross cut) }\end{array}$}} & \multicolumn{6}{|c|}{ Limbah } \\
\hline & & \multicolumn{3}{|c|}{ Serbuk } & \multicolumn{3}{|c|}{ Sabetan } \\
\hline $\begin{array}{l}\text { Keping } \\
\text { (Kpg) }\end{array}$ & $\begin{array}{l}\text { Volume } \\
\left(\mathrm{m}^{3}\right)\end{array}$ & $\begin{array}{l}\text { Volume } \\
\left(\mathrm{m}^{3}\right)\end{array}$ & $\begin{array}{c}\mathrm{i} \\
(\%)\end{array}$ & $\begin{array}{l}\mathrm{b} \\
(\%)\end{array}$ & $\begin{array}{l}\text { Volume } \\
\left(\mathrm{m}^{3}\right)\end{array}$ & $\begin{array}{c}\mathrm{i} \\
(\%)\end{array}$ & $\begin{array}{l}\mathrm{b} \\
(\%)\end{array}$ \\
\hline 4.595 & 66,1930 & 1,1479 & 1,73 & 0,99 & 6,9708 & 10,53 & 6,03 \\
\hline
\end{tabular}

Keterangan :

i\% : Persentase dari bahan baku mesin

$\mathrm{b} \%$ : Persentase dari bahan baku kayu bulat

\section{Rendemen Produksi}

Rendemen merupakan perbandingan antara jumlah hasil produk kayu gergajian dengan jumlah bahan baku (Fatori 2013). Penghitungan hasil produksi (rendemen) dapat dilakukan dengan pengukuran langsung dari dimensi kayu hasil olahan tersebut, namun karena bentuk dari produk yang dihasilkan tidak beraturan (produk yang dihasilkan dari tiap mesin berbeda-beda) maka penghitungan rendemen dapat dihitung dengan menggunakan analogi pengurangan, yaitu dengan asumsi bahwa rendemen merupakan kebalikan dari limbah produksi, sehingga penghitungan volume produksi menggunakan rumus :

Volume produksi $\left(\mathrm{m}^{3}\right)=$ vol. bahan baku $\left(\mathrm{m}^{3}\right)-$ vol. limbah $\left(\mathrm{m}^{3}\right)$

$$
\text { Rendemen (\%) }=\frac{\text { Volume Produksi }\left(\mathrm{M}^{3}\right)}{\text { Volume Log }\left(\mathrm{M}^{3}\right)} \times 100 \%
$$

\section{Rendemen produksi pada mesin breakdown saw}

Produk dari mesin pengolahan breakdown saw adalah berupa belahan-belahan besar dari kayu bulat (2 sampai 6 belahan kayu) tergantung dari kondisi fisik dan ukuran kayu serta pertimbangan produk akhir yang akan dihasilkan sesuai permintaan pasar. Hasil perhitungan volume produksi dari bahan baku $115,52 \mathrm{~m}^{3}$ diperoleh hasil produksi sebanyak $110,6682 \mathrm{~m}^{3}$ atau rendemen sebesar $95,80 \%$.

\section{Rendemen produksi pada mesin ponny}

Mesin ponny merupakan tahapan lanjutan dari mesin breakdown saw dimana merupakan mesin pembelah untuk menentukan ketebalan produk yang diinginkan. Sehingga hasil produknya berupa papan-papan dengan ketebalan tertentu. Dari hasil perhitungan diperoleh volume produksi sebanyak 97,3834 $\mathrm{m}^{3}$ dari bahan baku $110,6682 \mathrm{~m}^{3}$, sehingga rendemen sebesar $88 \%$ dari bahan baku mesin ponny atau sebesar $84,30 \%$ dari bahan baku asal (kayu bulat).

\section{Rendemen produksi pada mesin resaw}

Setelah ukuran ketebalan dari mesin ponny maka tahapan selanjutnya pada mesin resaw ditentukan ukuran lebarnya sesuai dengan yang diinginkan sehingga pada tahapan mesin ini produk kayu olahan telah berupa papan atau balok yang telah rata semua sisinya. Dari hasil perhitungan diperoleh volume produksi sebanyak 66,1930 $\mathrm{m}^{3}$ dari bahan baku 97,3834 $\mathrm{m}^{3}$ sehingga rendemen sebesar $67,97 \%$ dari bahan baku mesin resaw atau sebesar 57,30\% dari bahan baku asal (kayu bulat). 


\section{Rendemen produksi pada mesin cross cut}

Cross cut merupakan mesin pengolahan terakhir, dimana pada tahapan mesin ini dilakukan pemotongan untuk menentukan panjang kayu olahan sesuai dengan kondisi fisik kayu dan permintaan pasar (Cahyono 2018). Dari hasil perhitungan diperoleh volume produksi sebanyak $58,0743 \mathrm{~m}^{3}$ dari bahan baku $66,1930 \mathrm{~m}^{3}$ sehingga rendemen sebesar 87,73 $\%$ dari bahan baku mesin resaw atau sebesar $50,27 \%$ dari bahan baku asal (kayu bulat).

\section{Rekapitulasi Rendemen dan Limbah Industri}

Rendemen dan limbah mesin breakdown saw

Pada mesin breakdown saw dari bahan baku sebesar $115,52 \mathrm{~m}^{3}$ diperoleh rendemen sebesar $95,80 \% \quad\left(110,6682 \mathrm{~m}^{3}\right)$ dan limbah yang dihasilkan berupa serbuk gergaji dengan persentase sebesar $4,2 \%\left(4,8518 \mathrm{~m}^{3}\right)$.

Rendemen dan limbah mesin ponny

Pada mesin ponny dari bahan baku yang masuk sebesar $110,6682 \mathrm{~m}^{3}$ diperoleh rendemen sebesar 88,00\% $\left(97,3834 \mathrm{~m}^{3}\right)$ atau sebesar $84,30 \%$ dari bahan baku asal $(\log )$ dan limbah yang dihasilkan berupa serbuk gergaji dengan persentase sebesar 12,00 \% (13,2848 $\mathrm{m}^{3}$ ) atau sebesar $11,50 \%$ dari bahan baku asal.

\section{Rendemen dan limbah mesin resaw}

Pada mesin resaw dari bahan baku yang masuk sebesar 97,3834 $\mathrm{m}^{3}$ diperoleh rendemen sebesar $67,97 \%\left(66,1930 \mathrm{~m}^{3}\right)$ atau sebesar $57,30 \%$ dari bahan baku asal $(\log )$ dan limbah yang dihasilkan berupa serbuk gergaji dan sabetan. Persentase serbuk gergaji sebesar 4,74 $\%\left(4,6208 \mathrm{~m}^{3}\right)$ atau sebesar 4,00\% dari bahan baku asal $(\log )$ sedangkan persentase sabetan sebesar $27,28 \%\left(26,5696 \mathrm{~m}^{3}\right)$ atau sebesar 23,00\% dari bahan baku asal.

\section{Rendemen dan limbah mesin cross cut}

Pada mesin cross cut dari bahan baku yang masuk sebesar $66,1930 \mathrm{~m}^{3}$ diperoleh rendemen sebesar $87,73 \%\left(58,0743 \mathrm{~m}^{3}\right)$ atau sebesar $50,27 \%$ dari bahan baku asal $(\log )$ dan limbah yang dihasilkan berupa serbuk gergaji dan sabetan/potongan. Persentase serbuk gergaji sebesar $1,73 \%\left(1,1479 \mathrm{~m}^{3}\right)$ atau sebesar $0,99 \%$ dari bahan baku asal $(\log )$ sedangkan persentase sabetan/potongan sebesar 10,53\% $\left(6,9708 \mathrm{~m}^{3}\right)$ atau sebesar $6,03 \%$ dari bahan baku asal.

Tabel 5. Produk hasil pengolahan pada sawmill PT. Berau Karya Indah

\begin{tabular}{lcccc}
\hline Jenis mesin & $\begin{array}{c}\text { Bahan baku } \\
\left(\mathrm{m}^{3}\right)\end{array}$ & $\begin{array}{c}\text { Hasil produksi } \\
\left(\mathrm{m}^{3}\right)\end{array}$ & $\begin{array}{c}\text { Limbah serbuk } \\
\left(\mathrm{m}^{3}\right)\end{array}$ & $\begin{array}{c}\text { Limbah sabetan } \\
\left(\mathrm{m}^{3}\right)\end{array}$ \\
\hline Breakdown Saw & 115,52 & 110,6682 & 4,8518 & 0,0000 \\
Ponny & 110,6682 & 97,3834 & 13,2848 & 0,0000 \\
Resaw & 97,3834 & 66,1930 & 4,6208 & 26,5696 \\
Cross Cut & 66,1930 & 58,0743 & 1,1479 & 6,9708 \\
\hline
\end{tabular}

Gambar 2

Perbandingan persentase produk

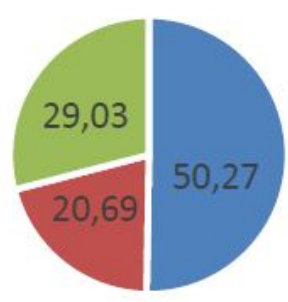

$$
\text { - Kayu Olahan - Limbah Serbuk - Limbah Sabetan }
$$


Dari gambar 5 terlihat persentase produk yang terjadi dari 24 batang kayu bulat dimana diperoleh rendemen produksi sebesar 50,27\%, serbuk 20,69\% dan sabetan sebesar 29,03\%. Besarnya limbah sabetan disebabkan karena saat produksi dari kayu bulat (bentuk yang tidak beraturan) menjadi bentuk yang persegi empat, selain itu diduga ada beberapa kayu bulat yang mengalami pecah sehingga menyebabkan terjadinya seleksi potongan lebih besar.

\section{KESIMPULAN}

Bahan baku industri yang masuk ke PT. Berau Karya Indah berupa kayu bulat yang dipasok dari IUPHHK PT. Manokwari Mandiri Lestari. Dalam pengoperasiannya, jenis mesin utama yang ada pada industri PT. Berau Karya Indah adalah breakdown saw, ponny, resaw dan cross cut. Persentase limbah yang dihasilkan pada proses pengolahan kayu adalah sebesar $49,73 \%$, dengan limbah yang dihasilkan dari breakdown saw berupa serbuk gergaji dengan persentase $4,20 \%$, limbah yang dihasilkan dari pony berupa serbuk gergaji dengan persentase $11,50 \%$, limbah yang dihasilkan dari resaw berupa serbuk gergaji dan sabetan dengan persentase limbah secara keseluruhan sebesar $27 \%$, yang terdiri dari limbah serbuk 4,00\% dan limbah sabetan $23,00 \%$, dan limbah yang dihasilkan dari cross cut berupa serbuk gergaji dan sabetan/potongan dengan persentase limbah secara keseluruhan sebesar $7,02 \%$, yang terdiri dari limbah serbuk $0,99 \%$ dan limbah sabetan/potongan 6,03\%. Bentuk pemanfaatan limbah hasil proses pengolahan kayu berupa sabetan atau potongan sebagian dimanfaatkan untuk bahan packing/palet, namun sebagian besar limbah baik sabetan maupun serbuk gergaji belum dimanfaatkan secara maksimal mengingat lokasi industri yang jauh dari lokasi pemukiman warga.

\section{DAFTAR PUSTAKA}

Cahyono EH. 2018. Perancangan ulang meja mesin cross cut dengan menggunakan metode Bencmarking (Studi kasus : UKM Meubel Bapak Rajimin). [Skripsi]. Program Studi Teknik Industri, Universitas Muhammadiah Surakarta, Yogyakarta.

Dinas Kehutanan Provinsi Papua. 2002. Profil potensi sumber daya hutan Provinsi Papua, Jayapura.

Fatori M. 2013. Peralatan dan mesin penggergajian kayu. Jilid I. Kementrian Pendidikan dan Kebudayaan Direktorat Pembinaan Sekolah Menengah Kejuruan, Jakarta.

ICW. 2004a. Industri pengolahan kayu, Kertas Kerja Nomor : 8 Greenomics Indonesia, Indonesia Coruption Watch, Jakarta.

ICW. 2004b. Evolusi hak, kewajiban dan sanksi terhadap sektor hulu dan hilir hehutanan, Kertas Kerja Nomor : 9 Greenomics Indonesia, Indonesia Coruption Watch, Jakarta.

Marwa J, Sardjono MA, Ruchaemi A, Devung S, Cabuy RL. 2019. Benefit sharing schema from the forest: Identifying potential distributions to customary communities in Teluk Bintuni district, Indonesia. Acta Universitatis Agriculturae et Silviculturae Mendelianae Brunensis. 67(4): 963-972. https://doi.org/10.11118/actaun20196704096 $\underline{3}$

Rianto R, Wahyudi, Djitmau DA. 2019. Potensi dan pemanfaatan limbah gergajian pada stand kayu di Distrik Manokwari Barat. Jurnal Kehutanan Papuasia. 5(1): 33-41. DOI: https://doi.org/10.46703/jurnalpapuasia .Vol5.Iss1.111. 